\title{
From Suspicion and Accommodation to Structural Transformation: Enhanced Scholarship through Enhanced Community-University Relations
}

\author{
Trish Van Katwyk and Robert A. Case
}

\begin{abstract}
While substantial efforts are being made in some universities to democratize the production, ownership, and use of knowledge through partnership with the community, significant barriers to community-university partnership persist, maintained through inequitable research relations, reductionist definitions of knowledge, and disincentives for faculty who are interested in community-based scholarship. The perseverance of this disconnect, we argue, is indicative of an existential aversion to community that lies deep within the psyche of the university. We liken the aversion to that of a disgust response, a social response that creates distance from that which is perceived to be dangerous, which in this case serves to preserve the university's privileged status as knowledge producer. In this paper we bring forward arguments for the importance of communityengaged scholarship to the university's civic role, to the pursuit of knowledge, and to the principles of democracy. We highlight promising advances in how some universities are accommodating community partnership within their definitions of scholarship and academic production, and, drawing upon Gordon's theory of structural transformation and Bourdieu's conceptualization of agency and habitus, we consider how such changes might be brought about at a deeper, structural level within the university.
\end{abstract}

KEYWORDs community-engaged scholarship, disgust response, habitus continuum of scholarship, structural transformation

Community-engaged scholarship represents a range of academic activities through which academia can and should break out of the narrow confines of the Ivory Tower, renew its relationship to community and society, and assert a civic role in building democracy and democratic practice. For that to occur, however, academia will need to challenge its own assumptions about knowledge, scholarship, and related practices so that it can support mutually beneficial and equitable collaboration.

The relationship between universities and communities has been scrutinized at various points in history, and is being scrutinized now. During the 1960s, the social divisions that supported an Ivory Tower of post secondary education were widely critiqued (Harkavy, 2006). At the same time, new approaches to scholarship were being devised, particularly at the progressive margins of academia, that challenged the superiority of positivist science methodologies (Denzin \& Lincoln, 2011). The elitist relationship between the world of scholars and the world of the people was seen, by this emerging academic movement, as negating the 
very social contract out of which post secondary education emerged (Harkavy, 2006). The goal of the movement was to bridge the town/gown divide, bringing greater democracy to knowledge production and dissemination in order to mutualize and expand the ways in which knowledge was validated and acquired.

Today, the rhetoric continues. Partnerships between the community and the university are being developed through university public relations efforts, and through collaborative research and teaching activities. Community-engaged scholarship is receiving much consideration in academia, evidenced by a proliferation of academic conferences and journals, increasing numbers of publications, programs and courses of study, and the growth of community-based settings for researchers in think-tanks, research groups and policy consultations. Increasingly, too, academic funders are prioritizing research programs that disseminate knowledge beyond the academy and into the world where it can be used. Open scholarship, with avenues such as open access, open data, and open educational pursuits, is another development supporting a philosophy of knowledge democratization that underlies the inception of the communityuniversity collaboration (Bhattacharyya, 2013).

Even so, the discourse and practices of the university cast a shadow of inequity across its relationship to the community. While showing openness to closer engagement with community in some quarters, universities are at the same time driven to keep re-asserting their privileged position by an increasingly competitive knowledge market and by opportunities presented with the commodification of knowledge that accompanies the neoliberal project (Bhattacharyya, 2013; Chomsky, 2015).

While the rhetoric supports a renewal of the community-university relationship, the practices of the university reproduce its privileged position based on a claim to a pure and rarefied pursuit of knowledge and a truth that is presumed unattainable in the community (Benson \& Harkavy, 2000; Bhattacharyya, 2013). Universities negate the capacities and knowledges of a diverse and experiential community that are at the heart of communityengaged and democratic scholarship. This resistance has become the focus of a number of discussions by scholars (e.g., Bhattacharyya, 2013; Cutforth, 2013), research methodologists (e.g., Battiste, 2002; Denzin \& Lincoln, 2011; Denzin, Lincoln \& Giardina, 2006; Martinez, 2013), social activists (Chomsky, 2012; Keith, 2008) and cultural critics (Bourdieu, 1986; Foucault, 1986; Raey, 2011).

While made visible through specific policies and practices of the university, the resistance of academia to engage fully with community in the production of knowledge is embedded in the psyche of academia as a disgust response. Related to the reaction that is activated when an individual encounters something that she or he perceives to be contaminated, the disgust response has been used to describe the social response to that which is considered to be different, a fear response that creates physical, emotional and social distance (de Melo-Martín \& Salles, 2011; Nussbaum, 2004; Taylor, 2007; Tyler, 2013).

In considering a way forward, we will explore a scholarship continuum that would include community-based learning, research, and knowledge mobilization activities in its recognition of rigorous scholarship. We will also consider the theoretical work of black studies scholar, 
Edmund T. Gordon (1995), and cultural critic, Pierre Bourdieu (1977, 1996), in terms of the possibilities of creating the deep institutional and cultural change that is necessary to strengthen a relationship between community and university. Gordon's theoretical work acknowledges the depth of change that is necessary because of the privileges the university has in sustaining a university-community divide. Bourdieu's theoretical work parallels Gordon's description of the levels of changes that need to occur. Additionally, Bourdieu's work contributes to a theory of change through its depiction of a social field that is continually being negotiated and renegotiated by the actions and exchanges of the field participants. The relations of a field do not remain static; they are continually exposed to the possibilities of change, and one change can effect more change, so that eventually the deep, cultural change as described by Gordon can be attained.

\section{Community Engaged Scholarship and the Civic Role of the University}

The notion that the university is bestowed with a civic mission is not new. As Biesta (2007) puts it, "the idea that the university has something to contribute to democracy and democratisation has a history that at least goes back to the Enlightenment and the emergence of the modern nation-state" (p. 478). Wilhelm Von Humbolt, who is credited with reinventing the modern university, believed that the pursuit of truth would "result in the enlightenment of the individual, society, the state, and mankind [sic] as a whole" (Biesta, 2007 p. 460). By maintaining a distance from community based on epistemological presumptions, and thereby eschewing the significant contributions to be made by community-based research initiatives and community-engaged scholarship, the university falls short of fulfilling its civic role.

Beginning in the 1990s, a renewed call for socially conscious, democratic higher education has been sounded (Cutforth, 2013). The Wingspread Declaration, which emerged from a conference attended by provosts, university presidents, deans and faculty members, as well as various community-based leaders, proclaimed community-engaged scholarship as an important and strategic means of renewing the university's civic mission (Boyte \& Hollander, 1999). The purpose of the conference was to "formulate strategies for renewing the civic mission of the research university, both by preparing students for responsible citizenship in a diverse democracy, and also by engaging faculty members to develop and utilize knowledge for the improvement of society" (Boyte \& Hollander, 1999, p. 3). The resultant Wingspread Declaration put forth an argument for community-engaged scholarship as democratic practice with recommendations to assist academic institutions in altering their relationships with the wider community.

In 2000, the W. K. Kellogg Foundation developed a report that critiqued the privileging of academic scholarship to the exclusion of meaningful consideration of the service and teaching activities of faculty. This report advocated for academic activities that are transformative for society and for our institutions (Astin \& Astin, 2000). The Boyer Commission Report (1990) similarly critiqued the disproportionate value being placed on research and publications (Kenny, 1998), energizing a public demand for academia to connect more overtly to social and political events (Calleson, Jordan \& Seifer, 2005). While university-community "partnerships" did already 
exist, the dynamics of those relationships were critiqued for maintaining the centrality and supremacy of the academic institution rather than promoting reciprocity and mutuality. The Boyer Report advocates, among other things, for a community-engaged approach to scholarship in which the university and the community collaborate as equal in the production, dissemination and use of knowledge.

Similarly, the Talloires Declaration, developed by educational leaders in Talloires, France, in 2005, and represented by a network of 240 universities in 62 countries (Hollister, Pollock, Geiran, Reid, Stroud \& Bancock, 2012), also commits to socially engaged scholarship. In this declaration, we see the opportunity for a shift in the power of the university over the community through inclusive educational practices, an openness to new knowledges, and a reciprocal interconnectedness to society and its realities.

\section{Democratic Knowledge}

Most fundamentally, community-engaged scholarship is proposed as a means of democratizing research and scholarship by breaking through the university's monopoly claim on knowledge and truth. Community-engaged scholarship involves practices that presume mutuality rather than elitism, that recognize shared and equitable expertise, and which value as equal the standard of knowledge and experience that the community has to offer. Communityengaged scholarship introduces a method of validation for alternative epistemologies; it seeks to alter the relationships that traditionally are organized around scholarship; and it demands that engagement with the university bring about positive social change for the everyday lives impacted by research activities. By democratizing the production and use of knowledge, community-engaged scholarship is promoted by some as an effective way by which structural change can occur (Kecskes \& Foster, 2013). Some current literature, in fact, suggests that to fulfill its civic role, it is an ethical imperative of academia to base its scholarly activities in the community as an intentional strategy contributing to structural transformation (Bhattacharyya, 2013; Keith, 2008; Ross, 2012).

\section{Epistemological Impact}

Accompanying the call for a renewed civic role for the university have been considerable developments in approaches to research, knowledge and truth that break from the positivist scientific traditions upon which the university's knowledge monopoly and status has historically been situated. Many of the developments in qualitative research that have occurred since the early 1990s began with a critique of the impact on community of research methodologies that were built upon the premises of positivist science (Denzin \& Lincoln, 2011; Denzin, Lincoln \& Giardina, 2006). Qualitative research begins with the assertion that truth is multiple and contingent, and that there are valuable knowledge sites to be found outside of controlled settings and the contaminant-free laboratory. Rejecting the idea that the 'laboratory' can ever be truly bias free, due to the ways in which social constructions influence observation and interpretation (Denzin \& Lincoln, 2011), qualitative researchers attend reflexively to the power dynamics of the research relationship and the ways in which those being researched can share 
equitably in the research that is being conducted.

As Denzin et al. (2006) observe, "Critical, interpretive qualitative research creates the power for positive, ethical, communitarian change, and the new practitioners entering this field deeply desire to use the power of the university to make such change" (p. 779). Many qualitative research approaches challenge a restrictive and absolutist notion of knowledge, finding value in personal stories, mundane details, and unique expression. With the rise of qualitative methods, it was possible to include previously marginalized knowledges (Denzin, Lincoln \& Giardina, 2006; Howe, 2004), such as those from Indigenous worldviews, those based in the experiences and analyses of women or people of non-Euro-Western descent, and those derived from observation at the community level. Through advances in social science approaches and qualitative methodologies, research relationships could shed many of the hierarchical power dynamics so that the researched were less vulnerable to exploitation and misconstruction and more deeply connected to the knowledge generated.

\section{Science, Knowledge and Neoliberalism}

Collaborative, reciprocal relations that produce and mobilize knowledge that can influence societal change is the promise that a transformed non-positivist conceptualization of science holds (i.e. Battiste, 2002; Denzin, Lincoln \& Giardina, 2006; Martinez, 2013; Loewenson, Laurell, Hogstedt, D’Ambruoso \& Shroff, 2014). Recently, however, there has emerged a strengthening resistance to this transformation. Positivist methodologies are being reintroduced as the prevailing means by which to produce valid knowledge, partially in response to the pressures of neoliberalism (Denzin \& Lincoln, 2011). Increasingly, education philosophers and other observers scrutinize the university in our current era for what they see as a corporatized restructuring of its activities and culture. While reform, active citizenship, and community-engagement are being espoused at the level of rhetoric for many universities, the development of a corporatized academic environment erects great obstacles to meaningful engagement with the community, maintaining a status quo that best suits the market. It is precisely the "civic engagement" with communities once treated as subjects of research, we believe, that scholars can help to resist these trends and promote "learning as a popular and democratic activity that resists the hierarchies and exploitative social relations fostered by education as we know it" (Bhattacharyya, 2013, p. 1414)

\section{Relationship Between University and Market}

Delanty (2001) identified a number of important historical moments in the evolution of the modern university, each of which has some bearing on the relationship of the university to society. As Paleari, Donina and Meoli (2015) point out, drawing on Delanty's work, in the middle of the nineteenth century, universities evolved from a repository of rarefied knowledge generated by "rule-governed communities of scholars" to sites of scientific knowledge production "through rational inquiry and experimentation" (p. 370). Universities became central institutions in academic training and scientific knowledge for both the civic needs of the nation-state and the economic needs of the second industrial revolution. Propelled by 
the broader neoliberal project, Paleari et al. (2015) argue, a "third mission" has crept into the university at the end of the twentieth century that has involved the university more directly in entrepreneurial activities and direct roles in private-sector development.

"Whereas in industrial societies there existed an indirect relationship between knowledge production and the economy," Biesta (2007) reminds us, "in post-industrial societies knowledge has become an economic force in its own right" (p. 468). "Academic capitalism" is used by some scholars to describe the way in which policies and practices of universities have begun, over the past two decades, to more closely reflect those of the private sector (Cernat, 2011; Slaughter \& Rhodes, 2004). In the context of academic capitalism, knowledge has increasingly come to be "regarded as a commodity rather than a free good," causing universities to organize themselves to profit from these commodities (Slaughter \& Rhodes, 2004, p. 170). The identification, creation and commercialization of intellectual property have thus emerged as "institutional objectives" for many universities and other academic institutions (Etzkowitz, Webster, Gebhardt \& Terra, 2000). With growing commercialization and commodification, the civic role of the university and the idea of knowledge as public good gets pushed aside in favour of "applied research serving corporate interests" (Cernat, 2011, p. 293).

Market discourse has become a predominant characterization of academic experience (Weiler, 2011). Knowledge becomes a commodity that faculty members owe to the students who have entered academia as customers. Knowledge acquisition becomes a mechanism by which to gain credentials and skills in order to succeed in the marketplace, rather than a goal in its own right. Post-secondary education programs are marketed for their exchange value - as “'investments' in one's future employability” (Biesta, 2007, p. 468). Educational theorist Michael Apple (2001) describes how, with the neoliberal turn in academia, the practices and objectives of the university become bound by marketplace discourse, including ingrained notions of accumulation, private property, and economic growth. With an accompanying neoconservative ideology, an embrace of tradition emerges: a resistance against progressive developments such as non-positivist conceptualizations of objectivity, knowledge, and the pursuit of multiple, interpretive truths. Apple (2001) describes an academic environment that has an allegiance to both 'pure' evidence and economic growth. Such an environment helps to sustain and promote a neoliberal hegemony that does not produce or mobilize knowledge in order to transform unjust structures of society. Evidence itself is left un-scrutinized for the power dynamics hidden within traditional conceptualizations of validity and rigour, or for the power imbalances that compel the manner of observations that are made and those that are omitted (Weiler, 2011).

\section{Rigour, Control, Power and Knowledge}

The university occupies an important space among the dominant institutions of society on the basis of its claim to expertise and knowledge. "Schools exist through their relations to other more powerful institutions," Apple (1979) has shown, "institutions that are combined in such a way as to generate structural inequities of power and access to resources" (p. 63). By occupying a privileged position within these institutional arrangements, moreover, universities

Engaged Scholar Journal: Community-Engaged Research, Teaching, and Learning 
are among the institutions that serve to reinforce and reproduce these inequities (Apple, 1979, p. 63). Increasingly, in the neoliberal era, the university finds itself "at the intersection of two important powers" (Cernat, 2011, p. 298): the market and the state. Our consideration of knowledge and the community-university relationship takes place in the self-perpetuating power dynamics of the "triple-helix" of academia-government-industry relations that has emerged in the post-industrial era of the knowledge economy (Etzkowitz et al., 2000).

Foucault (1976) scrutinized the methods by which knowledge is validated and propagated, theorizing that those in positions of power determine the methods of validating knowledge. Applying a similar analysis to the university, Biesta (2011) points out that as the only institutions with degree-awarding powers, universities have a monopoly on "who counts as a qualified researcher" and thus considerable influence over the kind and standard of knowledge that counts as legitimate (p. 471). "I do believe," concludes Biesta, "that de facto Universities ... play a crucial role in the definition of what counts as 'scientific' and what, in the wider society, is seen as "scientific"' (2011, p. 471).

In the era of the knowledge economy, universities increasingly find themselves competing on a global research market rather than complacently enjoying a "unique or privileged position within it" (Biesta, 2011, p. 470). With an ever-expanding range of institutions and agencies involving themselves in research, the university is compelled existentially to protect its status by articulating its hold on a special kind of knowledge or knowledge of a particular quality. The university thereby discounts and distances itself from research approaches that cannot be contained within the institutional arrangements of university and its rarefied expertise.

Foucault (1976) described a number of other ways in which universities undermine the pursuit of broad-based democratic participation, for instance, through pedagogical practices that make students docile and agreeable rather than critical and creative. Martinez (2013) uses Foucault's analysis in her examination of academic writing and finds that through the writing practices of the university, the student is relegated to a marketable, pro-capitalist body. Sterzuk (2015), similarly, argues that standards of language built into university education and culture serve to deactivate diversity: "Canadian educational institutions have historically served as homogenising agents for a heterogeneous population” (p. 58). Keith (2008) also describes the immobilizing effects of a bureaucratic approach to learning that seeks to transform knowledge into convenient units of product. Rationalized in epistemological terms, the university's monopoly on knowledge does not advance knowledge and promote democracy but instead reinforces the university's status and power by marginalizing other forms of knowledge production. If the university's form of knowledge is "more true, more real, more rational," then "the civic role of the university becomes confined to that of the expert" (Biesta, 2007, p. 471), and the university can claim the power to overrule all other understandings and viewpoints.

Bourdieu's (1977a, 1986, 1996, 2000) work complements Foucault's power/knowledge theorizing by describing academia as a social field organized along lines of status and power. Bourdieu's work focuses on understanding how the exchange of different forms of capitaleconomic, cultural, social and symbolic capital—explains how power and privilege reproduce 
themselves. According to Bourdieu, the distribution of capital within a social field is statusdriven. With power, there are great opportunities for gaining capital. The social field of academia is organized according to different levels of status, and, as in any other field, capital within academia is dispersed according to the organization of status (Bourdieu \& Passeron, 2000). Thus, academia is an environment where capital is exchanged and earned. To gain status, increasing amounts of capital must be earned according to the rules of conduct (referred to by Bourdieu as habitus) that are relevant to the academic field.

When Bourdieu's theory of capital and status is connected to Foucault's theoretical binding of knowledge and power, an approach to knowledge acquisition and mobilization can be conceptualized that is contained by the habitus of academia, as well as by the constraints of status, both in the ways knowledge gets validated and the ways knowledge gets to be held. What is left in this conceptualization is a narrowing group of 'knowers' and a finite definition of 'knowledge'. The habitus of the academic field includes the practices and policies of the institutions that support particular approaches to knowledge acquisition and discourage others. Tenure and promotion expectations and decisions, for instance, are based on how scholarship is conceptualized. Research funding decisions are reliant upon a particular and narrow definition of legitimate knowledge production. Annual performance reviews are guided by a set of normalizing expectations about how scholarship is demonstrated. The impact of scholarly activities is measured according to a normalized standard of influence and influenced. The definition and measurement of impact, scholarship and acceptable science methodology is in the hands of those who exercise greater power in the academic field than those whose scholarly activities and methods are being assessed.

\section{The Disgust Response}

Knowledge is once more being contained within the purview of the university, wherein lie the ostensibly impartial experts, contaminant-free circumstances, and an unadulterated dedication to truth. All other forms of knowledge production, knowledge translation and truth are held suspect, unable to meet the standards of positivist science (even as those knowledges begin to find spaces within the university through departments such as Indigenous studies, women's studies and critical race studies, to name but a few). The community is perceived as full of contaminants, dangerously subjective to the point of becoming untruthful, and in need of handling with tremendous care and caution. Academia is the gatekeeper, navigating the passage of knowledge, reality, and truth. The university engages with the community from the distance of the rational expert who performs academic tasks on the community, with a clear separation between the producers of knowledge (academia) and the consumers of knowledge (community agents) (Saltmarsh, Hartley \& Clayton, 2009).

We suggest that the distance that is maintained, the suspicion with which the knowledge and activities of the community are regarded, and the normative practices that form seemingly impenetrable walls around academia, are automatic and non-rational enough to comprise an institutionalized gesture of repugnance and fear-a disgust response. We suggest, moreover, that such a response constitutes a prejudice and stigma that serves unjust outcomes such as 
the invalidation of diverse knowledges, elitist and exclusionary space, and the deactivation of civil citizenship and meaningful democracy. In the social context, the disgust response is an impulse that serves the function of effectively establishing and marginalizing an Other (de Melo-Martín \& Salles, 2011; Nussbaum, 2004; Taylor, 2007; Tyler, 2013). Through a disgust response, perceived danger can be avoided in the way a physical disgust response prevents one from eating spoiled food or exposing oneself to unhygienic environments. Applied to social situations, the disgust response associates danger or risk with an Other, thereby reinforcing a social hierarchy and the dynamic of marginalization. The one and the Other become entrenched in their different-ness, a duality in which one is far superior to the Other (Lupton, 2015).

The idea that a disgust response is implicit in many of our social institutions has considerable support in the literature. Law scholar Nussbaum (2004), for example, has examined how legal structures support disgust responses by making illegal not only that which is clearly proven to be dangerous, but also that which is imagined to be dangerous. Nussbaum has considered laws prohibiting homosexuality as being motivated by a fear of contamination related to nonnormative lifestyles. Nussbaum points out the ways in which social experience can become shaped by xenophobic ideas about danger.

Socially biased disgust responses are engrained in our institutions through apparatuses that sustain stigma and discrimination. Some scholars argue that the distancing mechanism serves the function of creating a division between what is right and what is wrong, so that moral and social standing become determinable (Deigh, 2006; Durham, 2011; Tyler, 2013). The social distance that is often established with people involved in the psychiatric system, with people with evident physical disabilities, with older adults and with people who are obese are clear demonstrations of the ways in which bias and discrimination become embodied by disgust responses (Krostka, Harkness, Thomas \& Brown, 2014). In a disgust response, moral superiority is presumed, so that the Other is conceptualized to be immoral, impure, and therefore to be avoided. Reinforced through socialization, the risk associated with the Other is often so visceral that the disgust response becomes disproportionately reactive (better safe than sorry) and exercised as a reflex that lies beyond the level of rational comprehension (Kroska et. al, 2014). As a response that is involuntary and usually unexamined (Oaten, Stevenson, \& Case, 2009), the disgust response shares similar characteristics with other social constructions and with ideology.

The binary between the university and the community, having withstood intensive and decades' worth of challenges, remains formidable, making the disgust response a particularly apt description of the mechanism that maintains this division. The divisions are woven deep into the fabric of academic culture, with the critical function of sustaining a power dynamic that maintains academia as the producers, custodians and brokers of knowledge. Researchers Denzin and Lincoln (2011) describe how the positivist sciences such as physics, psychology and chemistry are seen as the great accomplishments of Western enlightenment in their capacity to access an impartial and unbiased Truth. Even as challenges to positivist science have created revolutionary change in the fields of science and epistemology (Kuhn, 1962), its "legacy" 
remains, constricting democratic civic engagement for the university (Hartman, 2013, p. 68).

At times, community partners support inequitable relations by reinforcing the status of the university. Hollander (2009) discusses the difficulty of partnering in community-based initiatives whose personnel are reticent or unable to engage as equal partners in scientific study. Community partners may be less interested in challenging the status of the university than in leveraging that status through research 'partnerships' to strengthen funding requests and policy proposals. Community agencies are motivated to engage academic partners as "technical advisers" rather than as partners (Bhattacharyya, 2013, p. 1118). Without intellectual pursuits becoming engrained in the community-university relationship, there is little room for overcoming the university's presumed knowledge monopoly and engaging the public sphere in philosophical debates about important social issues (Bhattacharyya, 2013; Ross, 2012).

Even as challenges to the oligarchy of positivism have opened up new avenues of inquiry in the university, its legacy remains in the form of academic practices, university policies and professional trajectories that impede a sufficient move to community-engaged scholarship. A number of scholars have identified a gap between rhetoric and actual practice when it comes to community-engaged scholarship in universities (e.g., Calleson et al., 2005; Harkavy, 2006). Scholars have described how assessments of scholarly productivity and policies regarding promotion and tenure create disincentives to community-engaged research and the transformation of the community-university relationship (e.g., Kecskes \& Foster, 2013; Marrero et al., 2013). Cutforth (2013) has observed that professors engaging in communitybased work receive less institutional regard than the scholars whose university-based work gains national notoriety. Calleson et al. (2005) found that untenured faculty are more likely to be rewarded with promotion when they publish in peer-reviewed journals than for even highimpact community-engaged activities, making community engagement "too professionally risky" to pursue (p. 318). Calleson et al. (2005) explain how community-based research is unattractive to many faculty members, so that even when younger faculty members would like to pursue community-based opportunities, there are few seasoned peers available to provide mentoring support. There are fewer top-tier journals that publish community-engaged research, creating yet another disincentive.

The distancing effect of the disgust response is paradoxical in the case of communityengaged scholarship, as it occurs even as collaborative, mutual community engagement is being espoused as best practice for the university. Examined through the lens of the knowledge/ power dynamic, the paradox permits the university to sustain the rhetoric of reciprocal relations with a recognized knowledgeable community with a minimal consequent diminishment of the status and power. We would regard the state-university dynamic as one where an elitist university serves the neoliberal and neoconservative agendas of the state by obstructing a community-engaged democratic scholarship through which structural change can occur.

\section{Resolution: A Way Forward}

Our position is that for universities to resist the influences of neoliberalism in the pursuit of truth(s) and social justice, for universities to reclaim and reassert their civic mission, and to 
make universities relevant in an expanding epistemological world map, effort must be renewed to overcome the obdurate resistance to community engaged scholarship that has confined such scholarship to the margins of academia. The growing movement toward community engaged scholarship among academics in a variety of disciplines and in numerous institutions, we feel, represents "a resurrection of the belief that scholars enter the public as participants" (Battacharya, 2013, p. 1411), and a growing recognition of the "connections between theory and practice" and the implications of scholarship in and "for the world beyond the academy" (Cutforth, 2013, p. 27).

\section{Scholarship as a Continuum of Approaches}

To conceptualize an expanded knowledge production that includes a diverse range of approaches, Ellison and Eatman (2008) outline a flexible continuum of scholarship (adapted in graphical form in Figure 1). The continuum of scholarship, Ellison and Eastman (2008) posit, "conveys the university's commitment to innovation, diversity, and choice" (p. 10). One end represents the pursuit of knowledge through highly controlled research design and the other the most civically engaged, reciprocal scholarship and engagement. The continuum of scholarship depicts an epistemological spectrum that opens up the university to intellectually and culturally diverse approaches to the pursuit of knowledge and truth. Figure 1 depicts one possibility for a redefined scholarship. By presenting scholarship as existing on a continuum, a shift occurs that loosens a rigid singularity so that fluidity and autonomy can characterize a scholastic journey. With such a continuum, it is possible to fashion an approach to research, teaching and learning so that relationships can fluctuate and be designed to best address the objectives of the scholastic activity. At the moment, the left side of the continuum is taken for granted and the right side remains at the margins, as evidenced by the metrics used to assess academic productivity, the tendency to relegate community engagement to the area of "service" (Gelman, Jordan, \& Seifer, 2013, p. 59), and the priorities around which promotion and tenure are determined.

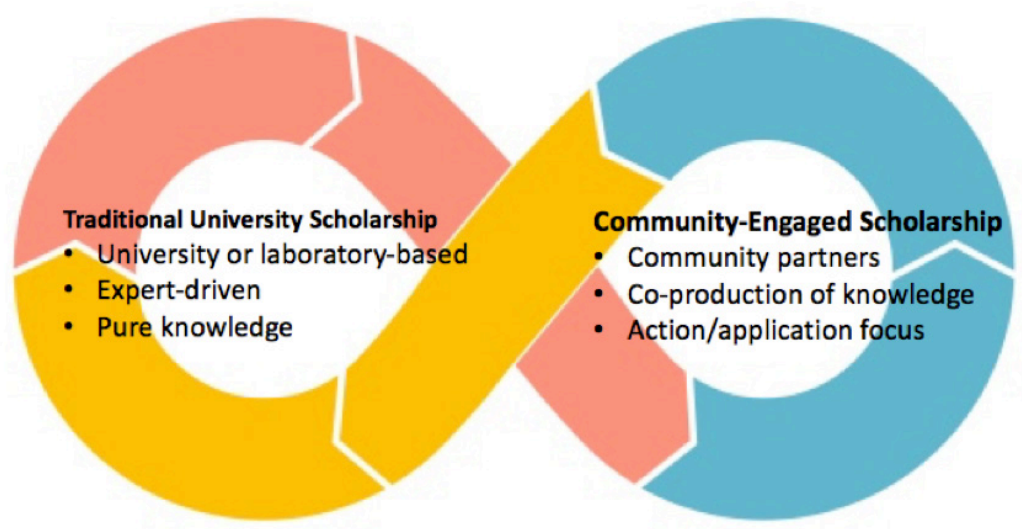

Figure 1: Holistic approach to scholarship. This figure depicts how scholarship might be conceived of as a continuum of approaches that includes community engaged scholarship 
Increasingly, community-engaged scholars are finding ways to position their work within the parameters of these processes, and some academic institutions are beginning to stretch the processes they use to incorporate metrics of considerable relevance to communityengaged scholarship. Some universities, for instance, are now accepting non-academics who are "experienced consumers of applied research" to sit on the promotion and tenure committees of scholars with community-based research portfolios (Gelman et al., 2013, p. 63). In some institutions, processes for verifying rigour and measures of academic productivity are expanded to include community-based alternatives to academic peer-reviewed publication and its associated metrics. Ideas are being concretized, too, in academic performance and tenure review measures that give credit for the thick and time-consuming process often involved in community-engaged research. Such process measures, Calleson et al. (2005) note, could be included alongside more traditional products and outcomes such as peer-reviewed publications.

\section{From Contextual to Transformational Change}

Resistance to the changes community-engaged scholars are looking for, however, is entrenched as a disgust response deep within the culture and psyche of the institution. While the degree of resistance varies across institutions and departments and although the efforts to create change have been multiple and impressive, the practices of the university as a whole remain significantly ensconced in an allegiance to expertise-driven, positivistic approaches to scholarship. As Kecskes and Foster (2013) state, "Universities are not known for their flexibility. While many appropriate adjectives exist to describe the institution of higher education on a global scale, nimbleness is not one of them" (p. 8). Sturm, Eatman, Saltmarsh, and Bush (2011) attribute this to the university's "cultural architecture" (p. 4), so that change is required (Marrero et al., 2013) at a cultural level.

\section{Considering Edmund T. Gordon}

Kecskes and Foster (2013) have considered this challenge and developed a theoretical framework for institutional transformation, drawing upon the work of Edmund T. Gordon, an anthropologist and black studies scholar, and building on the elaboration of Gordon's work by Kraehe, Foster and Blakes (2010). Kecskes and Foster (2013) describe three stages of change: contextual interventions, structural interventions, and structural transformation. A contextual intervention is an action relevant to a particular academic activity that breaks with tradition but does not require significant institutional involvement. An example of this level of change would be the recognition of a faculty member's community-oriented publication as academic productivity. Structural interventions, by contrast, trigger more than a temporary response, resulting in some lasting change within the institution. The addition to the tenure review process for all applicants of new metrics designed to measure and acknowledge communityoriented research outputs would constitute a structural intervention. While representing positive accommodations, in both of these cases there may be little change to an underlying culture that privileges some forms of scholarship over others. In fact, such approaches may accomplish little more than some superficial public relations objectives and may even reinforce 
the university's privileged position by extending academic capitalism into new markets (Keckes \& Foster, 2013).

On the other hand, contextual and structural interventions can lead, if understood as a step in the process of change, to a deeper form of transformation (Kecskes \& Foster, 2013; Kraehe et al., 2010): "When universities adopt a transformational approach, the goal is to partner with community members, organizations, and institutions to substantively address pressing challenges of the day" (Keckes \& Foster, 2013, p. 11). Structural transformation occurs when universities go beyond contextual and structural interventions to challenge the cultural and institutional foundations that generate the conditions against which these interventions push. Contextual and structural interventions are not seen as the end goal of proponents of community-engaged scholarship but as a means of instigating foundational change.

\section{Considering Pierre Bourdieu}

Bourdieu's concept of habitus provides a similar path to transformation through incremental change introduced to a particular social field. For Bourdieu, agency and change are inevitable in any social field and thus transformation of the structures and relations in place to support particular ways of attributing status is always possible. Bourdieu (1986) refers to social spaces as fields and the individuals in the fields as active participant players. Each field has rules of play that the players continually re-negotiate. The game's rules are conceptualized as habitus, an internalized and almost automatic response to the norms and expectations by the players within that field. Typically, the playing of the game itself reinforces habitus through routinized deference to the internalized norms and expectations. Ultimately, however, habitus is malleable and constantly under negotiation, so that alternative behaviours - like contextual and structural interventions (Keckes \& Foster, 2013) — can begin to create change in habitus.

Akram (2012) and Sweetman (2003) describe the highly active component of Bourdieu's conceptualization of habitus. Habitus, Sweetman (2003) points out, dissolves the structureagency duality because it is with agency that social structure is embodied. In Lovell's (2007) analysis, Bourdieu's concept of field is as a field of play, negotiations that individuals engage in, constantly in motion as resources, status and capital are assessed, determined, withheld or exchanged. The players actively and continually engage in these negotiations; within social space, there is never non-action. Change in the field and in habitus does occur, as there is no static state of being, only a state that is perpetually in flux. When a contextual intervention occurs, some of the rules of play are altered, which can inspire further changes in the rules of play, until the entire field begins to be negotiated in a different way. When the rules of play are altered so that their effect ripples out, the outcome can be a transformation at the structural level. Bauder and Engel-Di Mauro (2008) also describe the impact of change at a micro level when they describe the prerogative of scholars to begin change efforts with a willingness to examine how scholars are themselves reproducing social relations. Bauder and Engel-Di Mauro (2008) thus insist that change must happen at this deeply personal and autoethnographic level to inspire broad positive social change and structural transformation. 


\section{Collaboration and Mutuality in Knowledge Production}

Many of those who champion community-engaged scholarship, it should be noted, do not argue for the abandonment or even a diminishment of traditional expert-driven, positivist approaches to research and knowledge. Expertise in understanding and solving social problems, in fact, is precisely what communities and community agencies seek through collaboration with academics (Saltmarsh et al., 2009). Rather, proponents of community-engaged scholarship seek to bring together diverse groups of "knowers" and diverse approaches to researchand to critique the processes that would stymie such opportunities - in order to produce the knowledge that society needs for addressing complex social problems (Cutforth, 2013).

Many examples are emerging in and around universities that demonstrate that rich and meaningful community engagement is not only possible, but occurring in significant ways. After both experiencing and witnessing the devastation of Hurricane Katrina, Tulane University in New Orleans, for example, established a "Centre for Public Service," as part of the university's Renewal Plan, to support "a university curriculum and research agenda by uniting academics and action, classrooms and communities" (http://www2.tulane. $\mathrm{edu} / \mathrm{cps} /$ ). Students and scholars there have been active participants in community-based renewal efforts, while also contributing to scholarship on community renewal, social change and community engagement. In Canada, the Research Shop, affiliated with the Community Engaged Scholarship Institute (http://www.cesinstitute.ca) at the University of Guelph, Ontario, has been providing community groups with research expertise through graduate student internships aimed at enhancing organizational capacity and program effectiveness while at the same time contributing to scholarship on community and program development.

In Trish Van Katwyk's work, new spaces are being carved out for Indigenous-Settler collaboration in knowledge co-production through canoe journeying (Freeman \& Van Katwyk, forthcoming, 2017). She has also explored the alternative knowledge production and mobilization that are accessed through participatory, arts-based research methods involving youth (Seko \& Van Katwyk, 2016; Van Katwyk \& Seko, 2017). She has received institutional support for both of these initiatives, reflecting a researcher-driven "structural intervention" at the institutional level (Keckes \& Foster, 2013). In Robert Case’s work (e.g., Case \& Zeglen, forthcoming), action-oriented research methods are being devised that involve social movement organizations in the co-production and dissemination of knowledge that, through collaboration from the earliest stages of research planning, serves both academic purposes and community action priorities.

What the movement toward democratic community-engaged approaches to knowledge production challenges is the privileging of a singular form of research and knowledge production to the exclusion of other forms of knowledge and other knowledge producers (Saltmarsh et al., 2009). Instead, what social constructionists, qualitative researchers and communityengaged scholars assert is that a diversity of perspectives on and approaches to research and knowledge production is an invaluable key to the overall project of truth-seeking. As with Dorothy and her companions as they drew back the curtain and encountered a Wizard of Oz stripped of his mystical pretences, a transformation can occur in the community-university

Engaged Scholar Journal: Community-Engaged Research, Teaching, and Learning 
relationship that, rather than hindering the pursuit of truth, will make the discovery of an expanded and more authentic truth possible. The continued development of communityengaged scholarship in the university is a vital step towards this transformation.

\section{Conclusion}

The purpose of this discussion was to look critically at the relationship between the university and the community, to seek to understand the persistence with which an inequality of power in this relationship has been organized, and, finally, to explore possibilities of transformation.

The relationship between the university and the community is sustained by multiple practices and structural apparatuses. This relationship is organized to reproduce only limited support of an epistemology that creates space for multiple knowledge sources, diverse methodologies, and relationships of mutuality between the community and the university. The division between the university and the community is tenacious, despite solid and persistent challenges to its existence. Such tenacity can be explained as being derived from a disgust response of the university towards the community and community involvement in knowledge production. Conveying derision, fear and contempt toward community, the disgust response keeps the community at arms' length as too undisciplined, too impure, and too self-interested to participate in the production of valid knowledge and objective truth. This disgust response, we argue, comes out of an ideology that resides deep within the psyche of the university. We suggest that while contextual and structural interventions that make room for communityengaged scholarship within a predominantly positivist research culture are an important step, the changes that would need to occur to establish equity, mutuality and authenticity in the community-university relationship, to re-invigorate the university's civic role, and to engage with community partners in the co-production of knowledge are structural and cultural.

Community-engaged scholarship can also occur in ways that do not alter the powerful position that universities hold in their relationships with community. When communityengaged scholarship is taken up as a means to tap into the technological developments occurring in the community, in order to bring them back to the university and then be used to develop a strong workforce, we are encountering a justified appropriation in the name of a robust neoliberal market. When community-engaged scholarship supports a service to society that reflects a charity model of the haves and the have nots, the power dynamic does not shift, and the university remains in a position of benign sovereignty.

Embracing scholarship as a continuum encompassing diverse epistemological standpoints and research approaches brings additional methods and knowledge producers into the collective pursuit of truth. The change that needs to occur can begin with deeply personal, momentary, and singular events. As each altered interaction has the potential of a ripple effect, institutional interventions can shift so that the un-relinquished goal of institutional transformation can occur. As players in the post-secondary field, academics can implement change, ever mindful that each change in play will contribute to larger and wider structural aberrations leading to structural transformation and a promising new scholarship. 


\section{About the Authors}

Robert A. Case, PhD, (corresponding author) is an assistant professor in the Social Development Studies Department at Renison University College, Waterloo, Ontario, Canada. Email: rob. case@uwaterloo.ca

Trish Van Katwyk, PhD, is an assistant professor in the Social Development Studies Department at Renison University College, Waterloo, Ontario, Canada

\section{References}

Akram, S. (2012). Fully unconscious and prone to habit: The characteristics of agency in the structure and agency dialectic. Journal for the Theory of Social Behaviour, 43(1), 45-65.

Apple, M. (1979). Ideology and Curriculum. London, UK: Routledge.

Apple, M. (2001). Educational and curricular restructuring and the neo-liberal and neo-conservative agendas: Interview with Michael Apple. Curriculo sem Fronteiras, 1(1), i-xxxvi.

Astin, A. \& Astin, S. (2000). Leadership reconsidered: Engaging higher education in social change. Paper 133. Battle Creek, MI: W. K. Kellogg Foundation. Retrieved from http:// digitalcommons.unomaha.edu/slcehighered/133

Battiste, M. (2002). Indigenous knowledge and pedagogy in First Nations education, a literature review with recommendations. Ottawa, ON: National Working Group on Education and the Minister of Indian Affairs, Indian and Northern Affairs Canada (INAC). Retrieved from http://www.afn.ca/uploads/files/education/24._2002_oct_marie_battiste_ Indigenousknowledgeandpedagogy_lit_review_for_min_working_group.pdf

Bauder, H. \& Engel-Di Mauro, S. (2008). Critical geographies: A collection of readings. Kelowna, BC, Canada: Praxis (e)Press. Retrieved from http://www.praxis-epress.org/CGR/CG_Whole. $\mathrm{pdf}$

Baum, (1900). The Wonderful Wizard of Oz. Chicago, IL: George M. Hill Company.

Benson, L. \& Harkavy, I. (2000). Higher education's third revolution: The emergence of the democratic cosmopolitan civic university. Cityscape: A Journal of Policy Development and Research, 5(1), 47-57.

Bhattacharyya, B. (2013). How can we live with ourselves? Universities and the attempt to reconcile learning and doing. Ethnic and Racial Studies, 36(9), 1411-1428.

Biesta, G. (2007). Towards the knowledge democracy? Knowledge production and the civic role of the university. Studies in the Philosophy of Education, 26(5), 467-479.

Bourdieu, P. (1977). Outline of a theory of practice. Cambridge, UK: Cambridge University Press.

Bourdieu, P. (1986) The forms of capital. In: J. Richardson (Ed.), Handbook of theory and research for the sociology of education (pp. 241-258). New York, NY: Greenwood.

Bourdieu, P. (1996). Physical space, social space and habitus. Vilhelm Aubert Memorial lecture, Report, 10. Oslo, Norway: Department of Sociology, University of Oslo. Retrieved from https://www. sv.uio.no/iss/forskning/aktuelt/arrangementer/aubert/tidligere/dokumenter/aubert1995. pdf

Bourdieu, P. \& Passeron, J.C. (2000). Reproduction in Education, Society and Culture. London, UK: Sage Productions. 
Boyer, E. L. (1990). Scholarship Reconsidered: Priorities of the Professoriate. Princeton, NJ: Carnegie Foundation for the Advancement of Teaching.

Boyte, H. \& Hollander, E. (1999). The Wingspread Declaration on renewing the civic mission of the American research university. Retrieved from http://compact.org/wingspread-declarationon-the-civic-responsibilities-of-research-universities /

Calleson, D.C., Jordan, C., Seifer, S.D. (2005) Community-engaged scholarship: Is faculty work in communities a true academic enterprise? Academic Medicine: Journal of the Association of Medical Colleges, 80(4), 317-321.

Case, R. (forthcoming). Exploring the ebbs and flows of community engagement: The pyramid of engagement and water activism in two Canadian communities. Journal of Community Practice.

Case, R. \& Zeglen, L. (in press). Do successful campaigns generate grassroots engagement? Insights from community-based water activism in two Canadian communities. Journal of Community Practice.

Cernat, M. (2011). The role of the university in the knowledge society: Ethical perspectives on academic research in the age of corporate science. Lex Et Sciencia International Journal, 1(18), 293-302.

Chomsky, N. (2012). The purpose of education. Interview: Learning without frontiers conference [Video file]. Retrieved July 6, 2015 from https://youtube/DdNAUJWJN08.

Chomsky, N. (2015). Neo-liberalism and higher education/society. Interview: Public engagement and the politics of evidence symposium, July 22-25, 2015 [Video file]. Retrieved June 27, 2015 from https://youtu.be/OE56bEhx8b8.

Cutforth, N. (2013). The journey of a community engaged scholar: An autoethnography. Quest, 65(1), 14-30.

Deigh, J. (2006). The politics of disgust and shame. The Journal of Ethics, 10(4), 383-418.

Delanty, G. (2001), Challenging knowledge: The university in the knowledge society. Buckingham, UK: Open University Press.

de Melo-Martín, I., \& Salles, A. (2011). On disgust and human dignity. The Journal of Value Inquiry, 45(2), 159-168.

Denzin, N.K. \& Lincoln, Y.S. (2011). The Sage Handbook of Qualitative Research, 4th edition. Thousand Oaks, CA: Sage Publications.

Denzin, N.K., Lincoln, Y.S., and Giardina, M.D. (2006). Disciplining qualitative research. International Journal of Qualitative Studies in Education, 19(6), 769-782.

Durham, (2011). Disgust and the anthropological imagination. Ethnos, 76(2), 131-156. doi:10.1080/00 141844.2010.547941

Ellison, J., \& T. K. Eatman. (2008). Scholarship in public: Knowledge creation and tenure policy in the engaged university. Syracuse, NY: Imagining America. Retrieved from http://imaginingamerica.org/ wp-content/uploads/2015/07/ScholarshipinPublicKnowledge.pdf

Etzkowitz, H., Webster, A., Gebhardt, C., \& Terra, B. R. C. (2000). The future of the university and the university of the future: Evolution of ivory tower to entrepreneurial paradigm. Research Policy, 29(2), 313-330.

Freeman, B. \& Van Katwyk, T. (2017). Testing the waters: Building relationships and alliances through a Two Row research paradigm. in Hart, M. (ed.). Indigenist Research in Practice. Fernwood Publishing. (Forthcoming). 
Foucault, M. (1986). Madness and civilization: A bistory of insanity in the Age of Reason (translated by Richard Howard). New York, NY: Vintage Books.

Foucault, M (1976). Power and Knowledge: Selected Interviews and Other Writings, 1972-1977. New York, NY: Pantheon Books.

Gelman, Jordan \& Seifer (2013). Rethinking peer review: Expanding the boundaries for communityengaged scholarship. International Journal of Research on Service-Learning and Community Engagement, 1(1), np. Retrieved from http://journals.sfu.ca/iarslce.

Gordon, Edmund T. (1995). Cultural politics of Black masculinity. Transforming Anthropology, 6(1-2): 36-53.

Harkavy, I. (2006). The role of universities in advancing citizenship and social justice in the $21 \mathrm{st}$ century. Education, citizenship and social justice, 1(1), 5-37.

Hartman, E. (2013). No values, no democracy: The essential partisanship of civic engagement movement. Michigan Journal of Community Service Learning, 19(2), 58-71. Retrieved from http:/ / hdl.handle.net/2027/spo.3239521.0019.205

Hollander, J. (2011). Keeping control: The paradox of scholarly community-based research in community development. Community Development Journal, 46(2), 265-272.

Hollister, R. M., Pollock, J. P., Gearan, M., Reid, J., Stroud, S., \& Babcock, E. (2012). The Talloires Network: A global coalition of engaged universities. Journal of Higher Education Outreach and Engagement, 16(4), 81-10.

Howe, K. (2004). A critique of experimentalism. Qualitative Inquiry, 10(4), 42-61.

Kecskes, K. \& Foster, K.M. (2013). Three questions for community engagement at the crossroads. The Journal of Public Scholarship in Higher Education, 3, 7-17.

Keith, M. (2008). Public sociology? Between heroic immersion and critical distance. Personal reflections on academic engagement with political life. Critical Social Policy, 28(3), 320-334.

Kenny, R. (1998). Reinventing undergraduate education: A blueprint for America's research universities. Princeton, NJ: Carnegie Foundation for the Advancement of Teaching. Retrieved from http://eric.ed.gov/?id=ED424840

Kraehe, A., Foster, KM., \& Blakes, T. (2010). Through the perfect storm: Contextual responses, structural solutions, and the challenges of Black education. Souls: A Critical Journal of Black Politics, Culture, and Society, 12(3), 232-257.

Krotska, A., Harkness, S.K., Thomas, L.S., \& Brown, R.P. (2014). Illness labels and social distance. Society and Mental Health, 4(3), 215-234.

Kuhn, T.S. (1962). The structure of scientific revolutions. Chicago, IL: University of Chicago Press.

Loewenson, R., Laurell, A. C., Hogstedt, C., D’ambruoso, L., \& Shroff, Z. (2014). Participatory action research in health systems: a methods reader, TARSC, AHPSR, WHO, IDRC Canada, EQUINET, Harare.

Lovell, T. (2007). Nancy Fraser's integrated theory of justice: A 'Sociologically rich' model for a global capitalist era? Law, Social Justice \& Global Development Journal, 1, 1-23. Retrieved from http://www.go.warwick.ac.uk/elj/lgd/2007_1/lovell

Lupton, D. (2015). The pedagogy of disgust: The ethical, moral and political implications of using disgust in public health campaigns. Critical Public Health, 25(1), 4-14. 
Marrero, D. G., Hardwick, E. J., Staten, L.K., Savaiano, D. A., Odell, D., Frederickson Comer, K., \& Saha, C. (2013). Promotion and tenure for community-engaged research: An examination of promotion and tenure support for community-engaged research at three universities collaborating through a clinical and translational science award. Clinical Trans Science Journal, 6(3), 204-208.

Martinez, S. (2013). "For our words usually land on deaf ears until we scream": Writing as a liberatory practice. Qualitative Inquiry, 20(1), 3-14.

Nussbaum, M.C. (2004). Hiding From Humanity: Disgust, Shame, and Law. Princeton, NJ: Princeton University Press.

Oaten, M. J., Stevenson, R. J., \& Case, T. I. (2009). Disgust as a disease-avoidance mechanism. Psychological Bulletin, 135(2), 303-321.

Paleari, S., Donina, D. \& Meoli, M. (2015). The role of the university in twenty-first century European society. Journal of Technology Transfer, 40(3), 369-379.

Raey, (2011). Schooling for democracy: A Common school and a common university? A response to "Schooling for Democracy". Democracy and Education, 19(1), Article 6. Retrieved from http:// democracyeducationjournal.org/home/vol19/iss1/6

Ross, L. (2012). Disrupting borders: A case study of engaged pedagogy. Journal of Community Service Learning, 19(1), 58-68.

Saltmarsh, J., Hartley, M., \& Clayton, P. (2009). Democratic Engagement White Paper. Boston, MA: New England Resource Center for Higher Education.

Seko, Y. \& Van Katwyk, T. (2016). Embodied interpretation: Assessing the knowledge produced through a dance-based inquiry. Aotearoa New Zealand Social Work, 28(4), 54-66.

Slaughter, S. \& Rhoades, G. (2004). Academic Capitalism and the New Economy: Markets, State and Higher Education. Baltimore, MD: John Hopkins University Press.

Sterzuk, A. (2015). 'The standard remains the same': Language standardisation, race and othering in higher education. Journal of Multilingual and Multicultural Development, 36(1), 53-66. doi:10.1080 /01434632.2014.892501

Strum, S., Eatman, T., Saltmarch, J. \& Bush, A. (2011). Full participation: building the architecture for diversity and community engagement in higher education. Paper 17. Syracuse, NY: Imagining America. Retrieved from http:// surface.syr.edu/cgi/viewcontent.cgi?article=1001\&context $=$ ia

Sweetman, P. (2003). Twenty-first century disease? Habitual reflexivity or the reflexive habitus. The Sociological Review, 51(4), 529-549.

Taylor, K. (2007). Disgust is a factor in extreme prejudice. British Journal of Social Psychology, 46(3), $597-$ 617.

Tyler, (2013). The riots of the underclass? Stigmatisation, mediation and the government of poverty and disadvantage in Neoliberal Britain. Sociological Research Online, 18(4), np. Retrieved from http:/ /dx.doi.org/10.5153/sro.3157

Van Katwyk, T. \& Seko, Y. (2017). Collective auto ethnographic exploration of dance, knowledge and self-injury. Forum: Qualitative Research, 18(2), Art.1.

Weiler, H.N. (2011). Knowledge and power: The new politics of higher education. Journal of Educational Planning and Administration, 25(3), 205-211. 